\title{
How do College Student Leaders Learn and Make Good Use of Marxist Philosophy - Thoughts on Reading the Book Learning and using philosophy Written by Comrade Li Ruihuan
}

\author{
Li Zhang $^{1, \text { a }}$, Yu Zhang ${ }^{2, b}$ \\ ${ }^{1}$ North China Electric Power University, School of Foreign Language, Baoding, Hebei, China \\ ${ }^{2}$ North China Electric Power University, School of Foreign Language, Baoding, Hebei, China \\ am15236294369@163.com, ${ }^{\mathrm{b}} 3032419402 @ q q . c o m$
}

Keywords: Student leaders, Marxist Philosophy, Basic point of view.

Abstract. The book Learning and using philosophy, written by Li Ruihuan, states the profound meaning of philosophy in plain language. Combined with the author's work experience, the book clearly expounded the basic point of view of philosophy, which is very beneficial for us make good use of philosophy. Student leaders play an important role in universities. In progress of assisting school-related work, whether they master the basics of philosophical point of view steadily and apply it properly relates to the smoothly development of school work. Combined with many cases in book Learning and using philosophy, the paper discussed that student leaders in college should link theory with practice successfully as written in the book, and simultaneously study well on views of materialism, view of practice and dialecticism.

\section{Introduction}

On December 3, 2013, Xi Jinping, the General Secretary, made an important speech on the eleventh collective study of CPC Central Committee Political Bureau. He pointed out that studying philosophy and applying Philosophy is a good tradition of our party, and he highly praised the significant role of Marxist philosophy in promoting our party's work. Learning from the general secretary's speech, we can fully recognize the importance of philosophy. However, it is not asking everyone to become a philosopher, and therefore neither necessary nor possible to make everyone delve into philosophy like a philosopher. What we advocate is to study the basic point of view of Marxist philosophy, and to guide our practical work with it.

The paper mainly discusses how to well learn and properly apply the basic view of Marxist philosophy of College Student Leaders, and therefore obtain continuously improvement on the level of awareness, and better ability for work. These basic views include: materialism, practice and dialecticism.

\section{View of Materialism}

Philosophy, as a theory about worldview, reveals the most general laws of development and change of things. To learn philosophy well and master the general laws help us to improve the ability in understanding the special laws and solving specific problems. Focusing on practical is the basic requirement of materialism and is the basic premise for perfect work. The "facts" we often mention in "seeking truth from facts" is the objective existence.

Our Ideological Line of CPC is to proceed from reality, integrate theory with practice seek truth from facts, and test and develop the truth in practice. However, there are many things around us have not been done with the spirit of reality. When organizing class meeting and activities, some student leaders just go through the motions and work on form instead of according to the requirements of the teacher, such as take a few photos, or gathering together to read files roughly, and so to say that they have completed the task. This negative phenomenon, full of formalism and empty talk, of fraud, is a 
typical case of not adhere to materialism. Organizing activities like this seems bustling but actually is useless and a waste of time and effort of the students.

As college student leaders, they should always insist on materialistic point of view, regard objective reality as the starting point, and have fully consideration of the issue, in line with the real situation, so as to make their work to see more effective results.

\section{View of Practice}

From a practical point of view and aiming at solve the problem of the relationship between man and the world, Marxist philosophy achieve a great revolution of philosophy. In our daily life of work and study, if only adhere to the practical viewpoint and link theory with practice, can we get better results of things.

In our life, there are a few college student leaders, taking thing for granted, lacking investigation awareness and contribution spirit. When they organize activities, sometimes they even do not go ahead test the waters, see the site, and try the taste, ask prices in advance. Finally, students they gather do not enjoy themselves and feel dissatisfied, after they have spent so much money and had such a long journey and did not eat anything. Moreover, some student leaders do not devote themselves into collective interests. Instead, they often call the shots once the collective activities come. These ways of doing things lacking spirit of sacrifice and care for classmates and others, will drive them away from the masses, and cause a phase separation between subjective and objective, cognition and practice.

Practice is the sole criterion for testing truth. Either the theory of things, or the documents at hand, or experience of our minds, they all need to be tested with practice. To analyze specific issues with specific methods, so that they will have unrealistic expectations, they will gain continuously accumulation of experience and lessons, and they will complete the tasks their teachers assign impressively.

\section{View of Dialectics}

Materialist dialectics provide the fundamental views and approaches for people to understand the world and transform the world. Whether in the natural, social, thinking areas, or on the analysis of complicated contradictions in actual work, materialist dialectics has its general methodological significance. According to dialectics, while deal with issues, we can adjust to changing circumstances, grasp opportunities and have strategizing visionary.

For college student leaders, it is necessary to often insist on dialectical point of view in dealing with many issues. For example, when dealing with small groups' problems, love problems, playing online games problems in school, they should not summarily reject and ban all, but see the positive side and the negative side at the same time to help everyone recognize the negative effects, and reasonably avoid disadvantage which may be caused. At the time of dealing with their relationships with teachers and students, they should also handle appropriately to make the original two seemingly contradictory relationships to harmony and win-win situation. For specific individuals, they must not only see his shortcomings and deficiencies, but also see his advantages and strengths, and use the same criteria and standards to look at and measure everyone.

In short, learning materialist dialectics helps to know complicated and generally linked things. Every object has its two sides which can transform from one to the other. At different times, different places, facing different things, it is necessary to analyze specific issues with specific methods and to think flexibly.

\section{Summary}

College students are the future of our nation, shouldering the mission of national rejuvenation. Among college students, college student leaders bear the specific responsibilities in the groups of 
students, which mean that there are higher requirements for their capacity and quality. The main task of college student leaders, under the guidance of teachers, is to well understand the situation of students, grasp the policy of school, solve practical problems, and help teachers manage school work. If they do not understand the philosophy of Marxism, they cannot grab useful element among complicated situation; they cannot link policies with concrete practice properly, so as to obtain effective implementation of policy; they cannot handle conflicts appropriately and solve problems successfully.

Although philosophy cannot take the place of specific science, it can help us get a better consideration and application of specific scientific. If college student leaders have good professional knowledge and work experience, and then use basic principles of Marxism to generalize their knowledge and experience, it will greatly enhance their leadership ability in adapting and controlling the overall. On May 17, 2016, in the work forum of philosophy and social science, Xi Jinping, the General Secretary, re-emphasized that philosophy and social sciences is an important tool for people to understand and transform the world, is an important force to promote the historical development and social progress. In college work, college student leaders should always bear in mind three links: to understand the situation, to analyze the contradictions, to consider the countermeasure, thus to learn and make good use of Marxist philosophy.

\section{References}

[1] Mao Zedong. Mao Zedong anthology (volume 1) [M]. Beijing: People's Publishing House, 2009.

[2] Li Ruihuan. Philosophy Study and Application[M]. Beijing: China Renmin University Press, 2009.

[3] Wang Weiguang. Good Learning and Application of Marxist Philosophy, Mastering Ace Industriously-Experience from study of a series of speech spirit of comrade $\mathrm{Xi}[\mathrm{J}]$. Philosophical Researches, 2014, 06: 3-8.

[4] Yang Chungui. Proper Philosophy Study and Application-Study from the Important Discourse of Comrade Xi on learning and using Marxist Philosophy [J]. Marxist Philosophy Symposium, 2014, 04: 3-16.

[5] He Xiaoying. Views on Today’s College Students Learning and Using Marxist Philosophy[J]. Theory and Contemporary, 2009, 06: 45-46.

[6] QuYe. Application of Materialist Dialectics in the School Management [J]. Journal of Liu Panshui Teachers’ College, 2004, 05: 11-13.

[7] Liu Baohua. Learning well Philosophy is the Basics, Using appropriately is the Key-Experience from study Popular Philosophy[J]. China Audit, 2003, 10: 63.

[8] Liu Yiqiang. Why does Xi Jinping Pay highly Attention to the Study and Application of Marxist Philosophy[J]. Literature of Chinese Communist Party, 2015, 03: 34-38. 